\title{
Lead sorption from aqueous solutions by kaolinite: laboratory experiments
}

\author{
Salih Muhammad Awadh ${ }^{1 *}$ and Ayad Abdul Hameed Yousif ${ }^{1}$ \\ ${ }^{1}$ Department of Geology, College of Science, University of Baghdad, Iraq \\ * Correspondence: salihauad2000@yahoo.com
}

Manuscript received: 20-02-2021, revised: 07-03-2021, accepted: 10-03-2021.

\begin{abstract}
The lead has adverse effects in contamination the aquatic environment, for this reason, a laboratory experiment was conducted using kaolinite collected from the Ga'ara Formation in western Iraq to be considered as a natural sorbent material that can be addressed lead $\left(\mathrm{Pb}^{2+}\right)$ from the aqueous environments. The Energy-Dispersive $\mathrm{X}$ ray Spectroscopy and atomic absorption spectroscopy clarifying very fine grains and pure phase with a very little quantity of quartz and have a number of active sites for adsorption. The sorption of kaolinite for the $\mathrm{Pb}^{2+}$ has been carefully tested by several designed laboratory experiments. Five lead solutions of different concentrations $(25,50,75,100$ and $125 \mathrm{ppm})$ were tested under different values of $\mathrm{pH}(1.3-9)$. The best sorption (94\%) has been recorded at $\mathrm{pH} 9$, with an equilibrium reaction time of $40 \mathrm{~min}$ of a solution with has initial concentration of $25 \mathrm{ppm} \mathrm{Pb}^{2+}$ and the solid-liquid ration of $1.25 \mathrm{gm}: 50 \mathrm{ml}$. The sorption reaction is endothermic with two main mechanisms were identified, the rapid ion exchange which gets at the beginning of the reaction during the first $10 \mathrm{~m}$, and ion exchange, which gets slow later due to form ionic complexes
\end{abstract}

Keywords: Sorption; Kaolinite; Lead; aqueous solution; environmental protection; lab experiment.

\section{Introduction}

The toxic heavy metals are pollutants of water, with a major concern for human health along with the environmental quality. They are commonly found dissolved in a different aqueous solution including drinking water causing dangerous for the environment [1]. Their concentrations in aquatic ecosystems, especially lead, cadmium, chromium, cobalt, nickel, vanadium, zinc, copper, iron and manganese have increased considerably as a result of inputs from human production and consumption activities. Consequently, it is necessary to find a method able to treat the environment. Lead $(\mathrm{Pb})$ is one of the heavy metals that is known to be highly toxic even at low concentrations in water [2]. Different methods (ion exchange, chemical precipitation, filtration and reverse osmosis) for reducing heavy metal from the aqueous solution are well known [3]. Most of these methods are costly and sometimes complex and not efficient. The sorption (adsorption and absorption) method is a promising technique for the removal of heavy metals from aqueous solutions [4]. This method depends on cation exchange capacity (CEC) and adsorption can be used for the elimination of such pollutants. Clay minerals have a wide range of environmental applications due to the high CEC and high surface area [5]. Bentonite is a very good adsorbent material for lead ions from the aqueous solutions [6]. Kaolinite $\left(\mathrm{Al}_{2} \mathrm{Si}_{2} \mathrm{O}_{5}(\mathrm{OH})_{4}\right)$ is the most abundant mineral of the kaolinite group used as an important industrial raw material used extensively as additive and filler in the paper, plastics, rubber, pharmaceutical and polymer industry [7]. In this research, the sorption efficiency of kaolinite in the removal of potentially harmful lead ions from aqueous solutions was detail studied. The kaolinite used in this research is natural kaolinite collected from the Ga'ara Formation that was tested for absorbent efficiency with several aqueous solutions containing different concentrations of lead. The process of sorption (adsorption and absorption) is considered to be one of the best water treatment technologies around the world. Lead due to its toxic and hazardous nature is possibly the most widespread, so it is targeted in this research due to its abundance in natural systems following anthropogenic and natural inputs. This research has been built on a set of laboratory experiments aiming to discuss the sorption efficiency of kaolinite as a natural scavenger that can be used to reduce the lead content from the aqueous solutions in a further contribution for the environmental protection. 


\section{Materials and Methods}

Sampling was carried out on kaolinite zone in the Ga'ara Formation, western Iraq, (Longitude $42^{\circ} 28^{\prime}$ E Latitude $33^{\circ} 31^{\prime} \mathrm{N}$ ), in which many kaolinite exposures have existed. A fresh kaolinite exposure was selected (Fig. 1). Enough quantity of kaolinite was collected for the laboratory experiments. Samples were prepared by drying, grinding, and weighing in the Laboratory of Geochemisrty, Department of Geology, College of Science, University of Baghdad. Kaolinite was dried in an electric oven at $60^{\circ} \mathrm{C}$ for $2 \mathrm{~h}$. Mineralogy of kaolinite was conducted at Geological Faulty, Warsaw University using the Energy-Dispersive X-Ray Spectroscopy (EDS). The laboratory experiments were designed and conducted using a batch procedure to investigate the sorption efficiency of kaolinite. Solutions with five concentrations $(25,50,75,100$, and $125 \mathrm{ppm}) \mathrm{of} \mathrm{Pb}^{2+}$ were prepared using a colorless standard solution of $\mathrm{Pb}\left(\mathrm{NO}_{3}\right)_{2}$. Distilled water was used for diluting solutions. The measurements of $\mathrm{pH}$, TDS and EC have been done using a Hanna $\mathrm{pH}$-meter with calibration solutions according to Perrin and Dempsey [8]. Filtration was used at the end of each experiment to separate kaolinite from the solution. The lead content (\%) adsorbed by on kaolinite was determined from the difference between initial concentration $(\mathrm{Ci})$ and final concentration $(\mathrm{Cf})$ of lead in the aqueous solutions by using the following equation:

$$
\mathrm{C}(\%) \text { of heavy metal }=[(\mathrm{Ci}-\mathrm{Cf}) / \mathrm{Ci}] 100
$$

The effects of $\mathrm{pH}$, initial concentration, ionic strength, time and solid-liquid ratio were studied to evaluate the kaolinite sorption capacity and lead ion behavior. Accuracy and precision were done and show that all chemical results are accepted according to [9], [10].

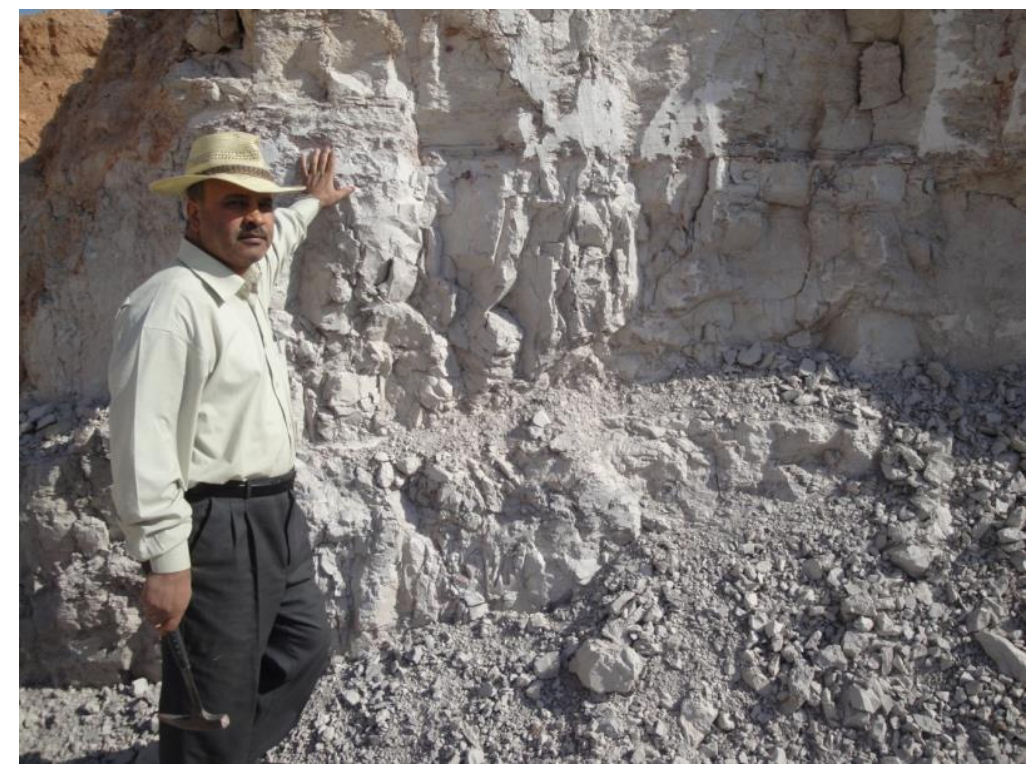

Figure 1. kaolinite deposits in the Ga'ara Formation used in this research.

\section{Kaolinite mineralogy and charge distribution}

The structure of kaolinite and mineralogy are presenting in Figs 2 and 3 respectively. Kaolinite has consisted of tetrahedral and octahedral layers. The tetrahedral layer contains a siloxane surface in which the main substitution is $\mathrm{Al}^{3+}$ for $\mathrm{Si}^{4+}$; resulted in a negative charge [11]. The substitution of $\mathrm{Mg}^{2+}$ for $\mathrm{Al}^{3+}$ is common in the octahedral layer resulted in a negative charge [12]. The knowledge of the charge distribution on the kaolinite surface would be helpful in the adsorption process. The formula of kaolinite is $\left(\mathrm{Si}_{4}\right)\left(\mathrm{Al}_{4}\right) \mathrm{O}_{10}(\mathrm{OH})_{8}$ indicates no substitution of $\mathrm{Si}^{4+}$ with $\mathrm{Al}^{3+}$ in the tetrahedral layer, and no substitution of $\mathrm{Al}^{3+}$ with $\mathrm{Mg}^{2+}, \mathrm{Fe}^{2+}$ in the octahedral layer, and $\mathrm{Ca}^{2+}, \mathrm{Na}^{+}$and $\mathrm{K}^{+}$in the interlayer. The net charge of kaolinite is calculated based on $\mathrm{Si}^{4+}$, $\mathrm{Al}^{3+}, \mathrm{O}^{2-}$ and the $\mathrm{OH}^{-1}$ as shown below:

$=[4(+4)]+[4(+3)]+[10(-2)]+[8(-1)]$

$=28-28$

$=0$

Kaolinite has a heterogeneous surface charge able to adsorb and absorb certain ions from aqueous solutions and maybe retaining them in an exchangeable state [13]. The exchangeable cations occur mostly on the edges and on the basal $\left(\mathrm{OH}^{-}\right)$surfaces of the kaolinite [14]. The permanent negative charge resulted from the replacement of $\mathrm{Al}^{3+}$ for $\mathrm{Si}^{4+}$ is insignificant. The $\mathrm{Al}^{3+}$ can substitute $\mathrm{Si}^{4+}$ in the tetrahedral layer resulting negative charge. Such this charge may participate to attract heavy metal ions like $\mathrm{Pb}^{2+}$ from contacted aqueous 
KBES 2021, 2, 1

solution. The charge distribution in each layer of kaolinite was calculated and presented in Table 1. The layers of tetrahedral and octahedral sheets charged will be balanced by interlayer cations such as $\mathrm{Na}^{+}, \mathrm{K}^{+}$or may be $\mathrm{Ca}^{2+}$. In each case, the interlayer can also contain water. A huge of tetrahedral and octahedral sheets connected together in kaolinite giving two types of planes $\mathrm{Si}, \mathrm{Al}, \mathrm{Mg}$ and $\mathrm{O}$ and $\mathrm{OH}$ group planes.

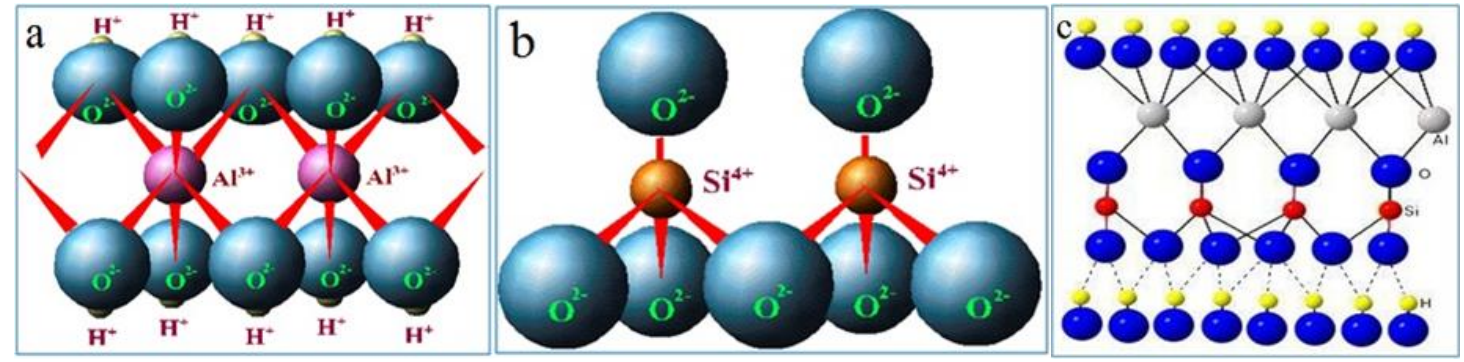

Figure 2. Kaolinite sheets and final structure. a: Tetrahedral sheet of kaolinite bound by shared oxygens; b: Octahedral sheet bound by shared oxygen atoms; c: Kaolinite structure.

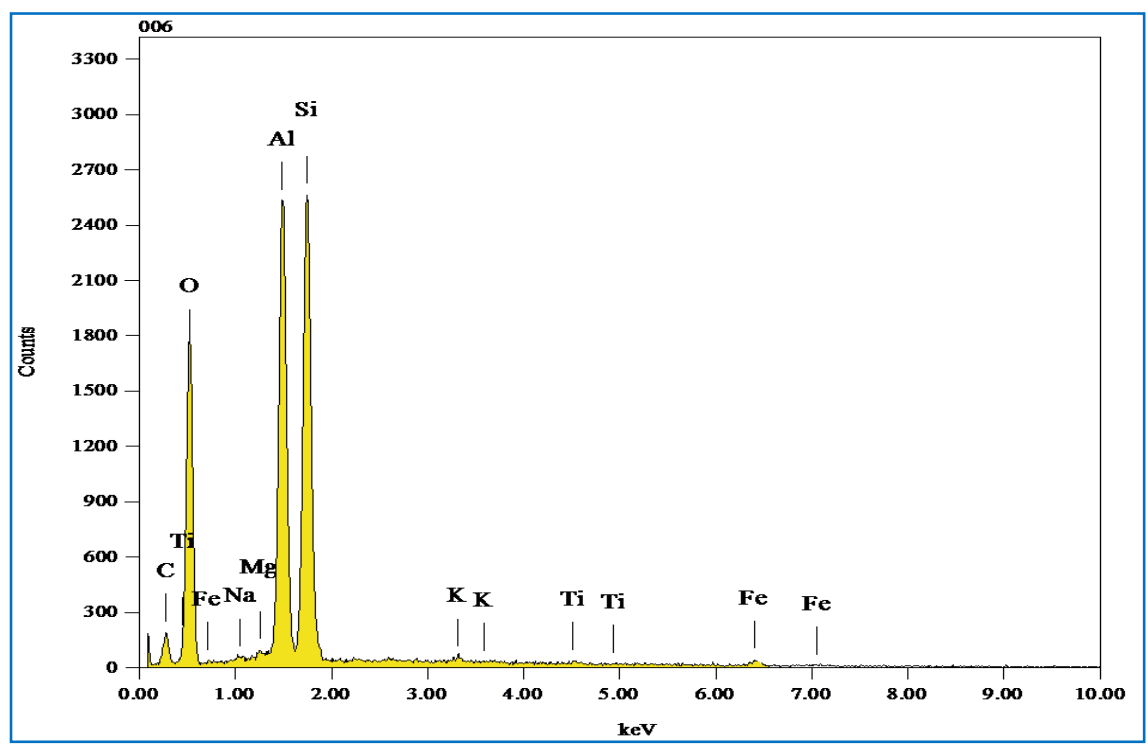

Figure 3. EDS spectra show the spectra of kaolinite.

Table 1. Calculation the charge distribution in the kaolinite structure.

\begin{tabular}{|c|c|c|c|c|c|c|c|c|c|c|c|}
\hline Oxides & $\%$ & M.W & $\begin{array}{l}\text { Mol } \\
\text { Equi }\end{array}$ & $\begin{array}{c}\text { Cation } \\
\text { Equi }\end{array}$ & $\begin{array}{l}\text { Charge } \\
\text { Equi }\end{array}$ & $\begin{array}{l}\text { Valency } \\
\text { Per } 28\end{array}$ & $\begin{array}{l}\text { Cation } \\
\text { Per }\end{array}$ & \multicolumn{2}{|c|}{$\begin{array}{l}\text { Distribution in } \\
\text { the lattice layer }\end{array}$} & \multicolumn{2}{|c|}{ Charge } \\
\hline $\mathrm{SiO}_{2}$ & 47.81 & 60 & 0.79 & 0.79 & 3.16 & 16.21 & 4.05 & \multirow[t]{2}{*}{ Tetrahedral } & $\mathrm{Si}^{4+} 4.05$ & \multirow[b]{2}{*}{8} & \multirow[b]{2}{*}{$\mathrm{Al}^{3+} 3.95$} \\
\hline $\mathbf{A l}_{2} \mathbf{O}_{3}$ & 35.11 & 102 & 0.34 & 0.68 & 2.04 & 10.46 & 3.48 & & $\mathrm{Al}^{3+} 3.95$ & & \\
\hline $\mathrm{Fe}_{2} \mathrm{O}_{3}$ & 2.50 & 160 & 0.015 & 0.03 & 0.09 & 0.46 & 0.15 & \multirow[t]{4}{*}{ Octahedral } & $\mathrm{Al}^{3+} 0.0$ & \multirow{4}{*}{0.223} & \multirow{4}{*}{3.49} \\
\hline MgO & 0.02 & 40 & 0.0005 & 0.0005 & 0.001 & 0.005 & 0.003 & & $\mathrm{Fe}^{3+} 0.15$ & & \\
\hline $\mathrm{CaO}$ & 2.21 & 56 & 0.039 & 0.039 & 0.078 & 0.4 & 0.3 & & $\mathrm{Mg}^{2+} 0.003$ & & \\
\hline $\mathbf{K}_{2} \mathbf{O}$ & 0.31 & 71 & 0.004 & 0.008 & 0.008 & 0.04 & 0.04 & & $\mathrm{Ti}^{4+} 0.07$ & & \\
\hline $\mathrm{Na}_{2} \mathrm{O}$ & 0.75 & 62 & 0.012 & 0.024 & 0.024 & 0.12 & 0.12 & \multirow[t]{3}{*}{ Interlayer } & $\mathrm{Ca}^{2+} 0.3$ & \multirow[b]{3}{*}{0.46} & \\
\hline $\mathrm{TiO}_{2}$ & 1.13 & 79.7 & 0.014 & 0.014 & 0.056 & 0.29 & 0.07 & & $\mathrm{~K}^{+} 0.04$ & & \\
\hline LOI & 10.3 & --- & --- & --- & --- & --- & --- & & $\mathrm{Na}^{+} 0.12$ & & \\
\hline Total & 100.14 & & & & 5.457 & 28 & & & & & \\
\hline
\end{tabular}

The releasing of $\mathrm{H}^{+}$and the adsorption of the $\mathrm{Pb}^{2+}$ could create an internal stress in the molecule. In addition to that replacing of $\mathrm{H}^{+}$instead of $\mathrm{Pb}^{2+}$ may be change the van der Waals forces in the kaolinite structure $[15]$.

\section{Results and discussion}




\section{$4.1 \mathrm{pH}$ value}

The CEC of kaolinite is mainly depended on the $\mathrm{pH}$ value [14]. A higher $\mathrm{pH}$ value gives rise to more negative charges leading to a higher CEC value. The charge on the edges of kaolinite depends on the $\mathrm{pH}$ value of the solution due to the protonation/deprotonation of exposed hydroxyl groups, whereas the basal siloxane surfaces have a constant structural charge due to the isomorphous substitution of $\mathrm{Si}^{4+}$ by $\mathrm{Al}^{3+}$ [13] .

This research shows that the hydroxyls on the exposed basal surfaces may be ionizable in aqueous solutions. Accordingly, the sorption efficiency of kaolinite was higher at high $\mathrm{pH}$ (alkali aqueous solutions). The $\mathrm{pH}$ value of the solution is one of the factors that clearly controls the adsorption property of the solution [16]. In the present study, $\mathrm{pH}$ was investigated through 4 experiments presented in Table 2 . The $\mathrm{pH}$ value has been observed by varying the $\mathrm{pH}$ of the kaolinite slurry in a wide range (1.3 - 9). The response of kaolinite sorption is illustrated in Fig. 4, which clearly reveals that good kaolinite sorption was at pH 5, but the optimal sorption was at pH 9.

Table 2. Results of sorption efficiency of kaolinite for $\mathrm{Pb}$ at different $\mathrm{pH}$.

\begin{tabular}{|c|c|c|c|c|c|c|c|c|}
\hline \multirow[b]{2}{*}{ No. } & \multicolumn{8}{|c|}{ Before experiment } \\
\hline & $\begin{array}{l}\text { Time } \\
\text { (min) }\end{array}$ & $\begin{array}{c}\text { Weight } \\
\text { mass } \\
(\text { gm) }\end{array}$ & $\begin{array}{c}C_{i} \\
(\mathbf{p p m})\end{array}$ & $\begin{array}{c}\text { Total } \\
\text { vol. } \\
(\mathrm{ml}) \\
\end{array}$ & pH & $\begin{array}{c}\text { TDS } \\
(\mathrm{mg} / \mathrm{l})\end{array}$ & $\begin{array}{c}\text { EC } \\
(\mu \mathrm{s} / \mathrm{cm})\end{array}$ & $\mathbf{T}\left(\mathbf{C}^{\mathbf{0}}\right)$ \\
\hline Pb1 & 10 & 2.0 & 100 & 50 & 1.3 & 9500 & 16150 & 24 \\
\hline $\mathbf{P b 2}$ & 10 & 2.0 & 100 & 50 & 5 & 9500 & 16150 & 24.1 \\
\hline $\mathbf{P b 3}$ & 10 & 2.0 & 100 & 50 & 7 & 9500 & 16150 & 24.2 \\
\hline Pb4 & 10 & 2.0 & 100 & 50 & 9 & 9500 & 16150 & 24 \\
\hline & \multicolumn{8}{|c|}{ After experiment } \\
\hline No. & pH & $\begin{array}{c}\text { TDS } \\
(\mathrm{mg} / \mathrm{l})\end{array}$ & $\begin{array}{c}\text { EC } \\
(\mu \mathrm{s} / \mathrm{cm})\end{array}$ & $\mathbf{T}\left(\mathbf{C}^{\mathbf{o}}\right)$ & \multicolumn{2}{|c|}{$C_{f}(\mathbf{p p m})$} & $\begin{array}{c}\text { Sorption } \\
(\mathbf{p p m})\end{array}$ & $\begin{array}{c}\text { Sorption } \\
(\%) \\
\end{array}$ \\
\hline Pb1 & 1.19 & 5400 & 8750 & 23.9 & \multicolumn{2}{|c|}{82.75} & 17.25 & 17.25 \\
\hline $\mathbf{P b 2}$ & 6.88 & 4800 & 7730 & 23.8 & \multicolumn{2}{|c|}{25.72} & 74.28 & 74.28 \\
\hline $\mathbf{P b 3}$ & 6.86 & 5100 & 8240 & 23.8 & \multicolumn{2}{|c|}{29.3} & 70.7 & 70.7 \\
\hline Pb4 & 7.11 & 3930 & 6360 & 23.7 & \multicolumn{2}{|c|}{6.66} & 93.34 & 93.34 \\
\hline
\end{tabular}

$C_{i}$ : Initial Concentration. $C_{f}$ : Final Concentration.

Many researchers, for example [17]-[19], have stated the maximum adsorption efficiency happens in the range $\mathrm{pH}$ 6-8; the decreasing negative charge density for lower adsorption efficiency above this $\mathrm{pH}$ [20], [21]. Before starting experiments, the TDS $(9500 \mathrm{ppm})$ and EC $(16150 \mu \mathrm{s} / \mathrm{cm})$ for the initial solutions are constant, because all solutions have the same $\mathrm{Pb}$ concentrations $(100 \mathrm{ppm})$ (Table 2); but after the experiment ended, TDS and EC were proportionally changed indicating good sorption has happened in $\mathrm{pH}$ 5, whilst $\mathrm{pH} 9$ was most favorite and the best for removing heavy metal ions from aqueous solutions (Table 2).

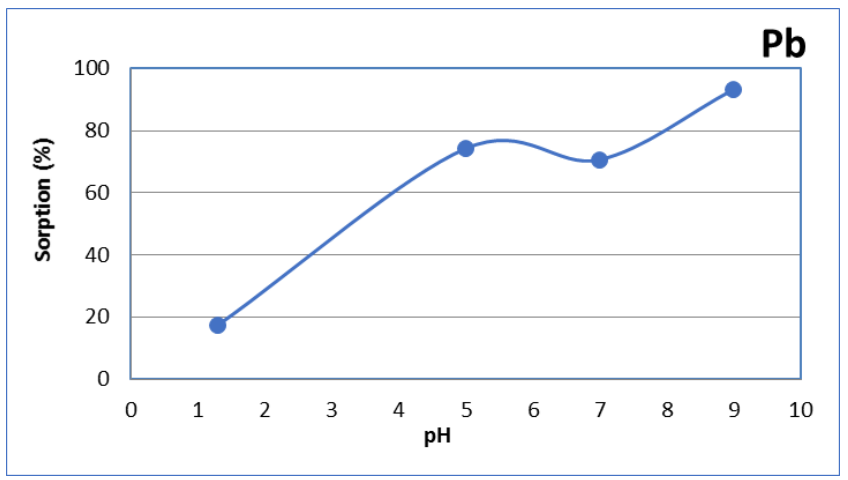

Figure 4. Response curve illustrating the $\mathrm{pH}$ affects the sorption of lead ions on kaolinite surfaces from a

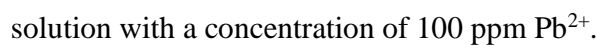




\subsection{Initial ion concentration}

Lead $\left(\mathrm{Pb}^{2+}\right)$ is controlled less by the cation exchange mechanism than most other heavy metals, meaning that adsorption of $\mathrm{Pb}^{2+}$ is highly influenced by $\mathrm{pH}$ [22]. The amount of adsorbed of $\mathrm{Pb}$ increases with $\mathrm{pH}$ ranges from 1 to 6 [23]. At high $\mathrm{pH}$, The $\mathrm{Pb}$ has high sorption on the vacant site on kaolinite. The substitution of $\mathrm{Pb}^{2+}$ (atomic radii $($ a.r. $\left.)=1.81 \mathrm{~A}^{\circ}\right)$, for $\mathrm{H}^{+}\left(\right.$a.r. $=0.79 \mathrm{~A}^{\circ}$ ) could produce stress in the kaolinite structure [15]. Laboratory experiments were conducted to investigate the influence of lead concentration on kaolinite sorption. For this reason, five initial solutions of $\mathrm{Pb}$ were prepared with concentrations of 25, 50, 75, 100 and $125 \mathrm{ppm}$. Then $50 \mathrm{ml}$ of these solutions were separately treated with $1.25 \mathrm{gm}$ kaolinite for $40 \mathrm{~min}$ at the condition of $\mathrm{pH}$ 9. The temperature along with the necessary dataset of these experiments are listed in Table 3. Upon the experiment ended, the $\mathrm{Pb}^{2+}$ concentrations in the final solutions become 1.5, 4.4, 7.3, 44.6, $70.3 \mathrm{ppm}$ respectively, with kaolinite sorption as 23.5, 45.6, 67.7, 55.4 and 54.7 ppm meaning 94, 91.2, 90.3, 55.4 and $43.8 \%$ (Table 3).

Table 3. Results of kaolinite sorption efficiency in removal $\mathrm{Pb}$ ions from the aqueous solution with different initial concentration.

\begin{tabular}{|c|c|c|c|c|c|c|c|c|c|c|c|}
\hline \multirow[b]{2}{*}{ No. } & \multicolumn{6}{|c|}{ Before experiment } & \multicolumn{5}{|c|}{ After experiment } \\
\hline & $\begin{array}{l}\text { Time } \\
\text { (min) }\end{array}$ & $\begin{array}{c}\text { Weight } \\
\text { mass } \\
(\text { gm) }\end{array}$ & $\begin{array}{c}C_{i} \\
(\mathbf{p p m})\end{array}$ & $\begin{array}{c}\text { Total } \\
\text { vol. }(\mathrm{ml})\end{array}$ & pH & $\begin{array}{c}\mathbf{T} \\
\left(\mathbf{C}^{0}\right)\end{array}$ & $\mathbf{p H}$ & $\begin{array}{c}\mathbf{T} \\
\left(\mathbf{C}^{\mathbf{o}}\right)\end{array}$ & $\begin{array}{c}C_{f} \\
(\mathbf{p p m})\end{array}$ & $\begin{array}{c}\text { Sorption } \\
(\mathbf{p p m})\end{array}$ & $\begin{array}{c}\text { Sorption } \\
(\%)\end{array}$ \\
\hline Pb-1 & 40 & 1.25 & 25 & 50 & 9 & 15.2 & 8.5 & 15.1 & 1.5 & 23.5 & 94 \\
\hline $\mathbf{P b}-2$ & 40 & 1.25 & 50 & 50 & 9 & 15.2 & 8.7 & 15.1 & 4.4 & 45.6 & 91.2 \\
\hline Pb-3 & 40 & 1.25 & 75 & 50 & 9 & 15.2 & 8.3 & 15.1 & 7.3 & 67.7 & 90.3 \\
\hline $\mathrm{Pb}-4$ & 40 & 1.25 & 100 & 50 & 9 & 15.3 & 8.8 & 15.1 & 44.6 & 55.4 & 55.4 \\
\hline Pb-5 & 40 & 1.25 & 125 & 50 & 9 & 15.2 & 9.0 & 15.0 & 70.3 & 54.7 & 43.8 \\
\hline
\end{tabular}

$C_{i}$ : Initial Concentration. $C_{f}$. Final Concentration.

The maximal sorption was on the initial solution of $75 \mathrm{ppm}$. The rate of kaolinite sorption for each concentration is illustrated in Fig.5. The initial concentration and the percent of sorption were described by the relationship shown in Fig.6 which confirms that the best kaolinite sorption is with an initial solution of 75 ppm $\mathrm{Pb}^{2+}$.

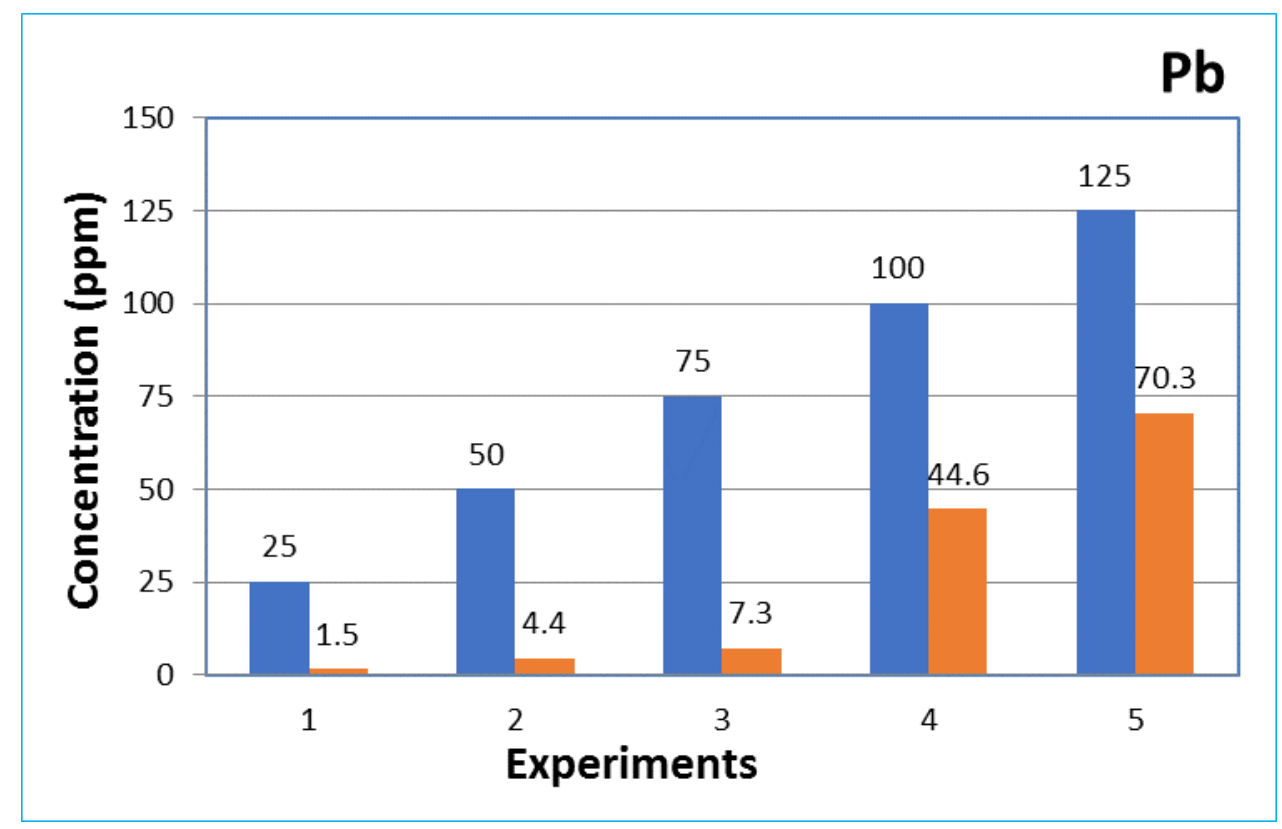

Figure 5. Lead ion concentrations before (blue column) and after experiment (red column) at pH 9, reaction time $40 \mathrm{~min}$, solid-liquid ratio is $1.25 \mathrm{gm}: 50 \mathrm{ml}$. 


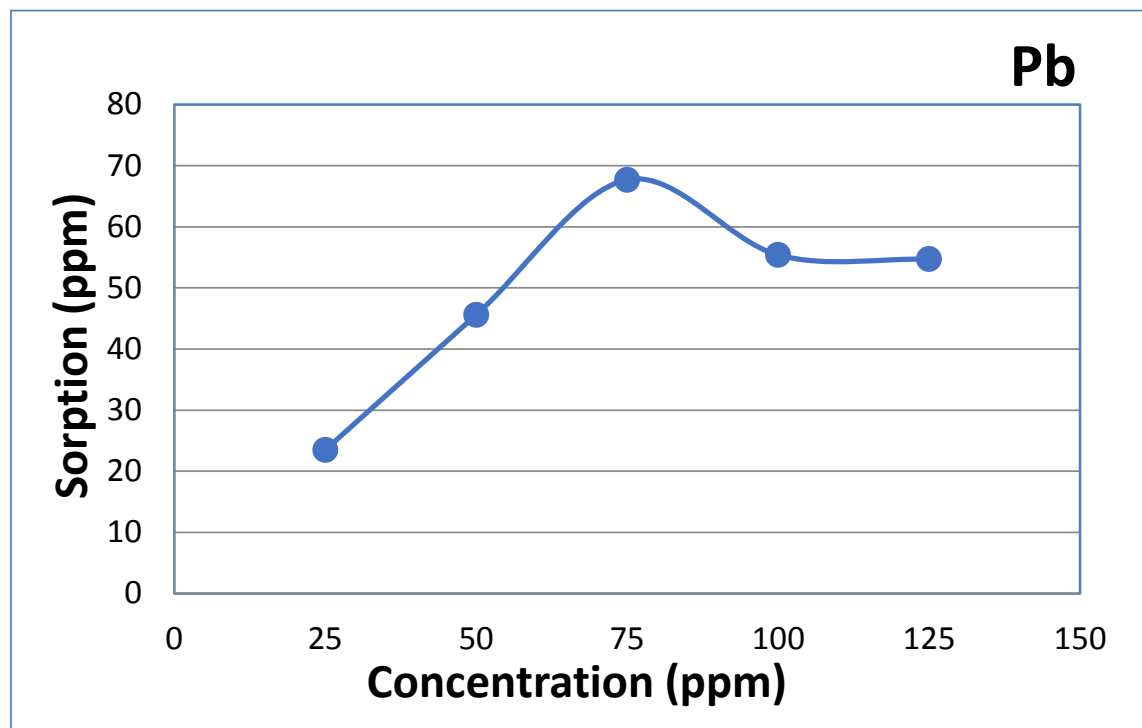

Figure 6. The response of kaolinte sorption $(\%)$ to the different $\mathrm{Pb}^{2+}$ concentrations.

All laboratory experiments indicate that the lead sorption on kaolinite was an endothermic reaction as temperature decreases after the experiment ended (Tables 3). Higher $\mathrm{pH}$ leads to a higher CEC value [24]. The removal efficiency of heavy metals by clay minerals decreases at lower $\mathrm{pH}$ values $(\mathrm{pH}<4)$ and increases at $\mathrm{pH}$ values up to 4 [21], [25]. The experiments in this research have been accordingly designated on $\mathrm{pH} 9$. The solid: liquid ratio was suggested by Yong et al [26].

as 1:10, but this research suggested a new ratio 1.25:50 due to the using of different lead concentration. The negative charge increases at the kaolinite surface due to the release of hydrogen ions from it after absorption of the lead ions. Adsorption onto kaolinite depends on the concentration of heavy metal ions in an aqueous solution [17]. The initial heavy metal concentration has been seen to have a considerable influence on the effect of increased contact time. When a higher initial metal concentration used a greater length of contact time is required to achieve complete sorption.

\section{Conclusions and recommendations}

The sorption characteristics of lead ions onto the kaolinite surface have been studied based on its adsorption ability as a function $\mathrm{pH}$, solid-liquid ratio, and ion concentration and equilibrium reaction time. Several findings from this research can by drown here:

i. Mineralogy has been shown that the kaolinite sheet structure provides a number of active sites for adsorption and therefore it has a good ability to remove heavy metals.

ii. It was found that the adsorption of lead ions onto kaolinite was strongly dependent on initial lead ion concentration in addition to $\mathrm{pH}$ values, where the sorption efficiency of led ions increases with $\mathrm{pH}$ till pH 9.

iii. The sorption efficiency of kaolinite in the removal of $\mathrm{Pb}$ ions was found to be influenced by $\mathrm{pH}$, initial concentration of heavy metal ions, contact time and solid-liquid ratio.

iv. Two major mechanisms control the kaolinite sorption, the initially rapid ion exchange phase happens for 10 minutes, and the slower inner-complex forming phase happens for 40 minutes.

v. The $\mathrm{H}^{+}$ions are released from the kaolinite structure, yielding an increase of negative charge on the surface. This mechanism was detected to be happening, particularly at initial solutions of high concentrations.

vi. Peak sorption of $\mathrm{Pb}^{2+}$ was happened firstly at the beginning of the experiment due to strong attraction occurred by substitution, and later adsorption needs more time to complete due to repulse and may be complex molecules formation.

Depending on the results of the current research, we recommend using kaolinite in the purification the contaminated aquatic environments, especially water and industrial effluents.

Acknowledgements: The authors are grateful to the staff of the Lab of Geochemistry at the University of Baghdad for providing the standard solutions. The authors also thank Dr. Krzysztof Nejbert from Geological 
Faculty at Warsaw University for his great effort helped us with the analytical analyses related to the EnergyDispersive X-ray Spectroscopy.

Conflicts of Interest: The authors declare no conflict of interest.

\section{References}

[1] P. Khanna, "Assessment of Heavy Metal Contamination in Different Vegetables Grown in and Around Urban Areas," Research Journal of Environmental Toxicology, vol. 5, no. 3, pp. 162-179, 2011.

[2] A. Sadeghizadeh, F. Ebrahimi, M. Heydari, M. Tahmasebikohyani, F. Ebrahimi, and A. Sadeghizadeh, "Adsorptive removal of $\mathrm{Pb}$ (II) by means of hydroxyapatite/chitosan nanocomposite hybrid nanoadsorbent: ANFIS modeling and experimental study," Journal of Environmental Management, vol. 232, no. July 2018, pp. 342-353, 2019.

[3] F. Fu and Q. Wang, "Removal of heavy metal ions from wastewaters: a review," Journal of environmental management, vol. 92, no. 3, pp. 407-418, 2011.

[4] G. Zhao, "Sorption of Heavy Metal Ions from Aqueous Solutions: A Review," The Open Colloid Science Journal, vol. 4, no. 1, pp. 19-31, 2011.

[5] Y. Xi, M. Mallavarapu, and R. Naidu, "Preparation, characterization of surfactants modified clay minerals and nitrate adsorption," Applied Clay Science, vol. 48, no. 1-2, pp. 92-96, 2010.

[6] S. M. Awadh and F. H. Abdulla, "Purification of aqueous solutions from Pb(II) by natural bentonite: an empirical study on chemical adsorption," Environmental Earth Sciences, vol. 76, no. 11, 2017.

[7] M. Garcia-Valles, P. Alfonso, S. Martínez, and N. Roca, "Mineralogical and Thermal Characterization of Kaolinitic Clays from Terra Alta (Catalonia, Spain)," Minerals, vol. 10, no. 2, p. 142, 2020.

[8] D. D. Perrin and B. Dempsey, "Metal-Ion Buffers," Buffers for pH and Metal Ion Control. Springer Netherlands, pp. 94-108, 1974.

[9] J. A. Winchester and P. A. Floyd, "Geochemical magma type discrimination: application to altered and metamorphosed basic igneous rocks,” Earth and Planetary Science Letters, vol. 28, no. 3, pp. 459-469, 1976.

[10] S. S. Goldich, C. O. Ingamells, N. H. Suhr, and D. H. Anderson, “Analyses of silicate rock and mineral standards," Canadian Journal of Earth Sciences, vol. 4, no. 5, pp. 747-755, 1967.

[11] Z. Zhou, "The Nature of the Surface Charge of Kaolinite," Clays and Clay Minerals, vol. 40, no. 3, pp. 365-368, 1992.

[12] Y. Hong, G. Chen, and L. Bushnell, "Distributed observers design for leader-following control of multiagent networks," Automatica, vol. 44, no. 3, pp. 846-850, 2008.

[13] H. Van Olphen, “An introduction to clay colloid chemistry,” Soil Science, vol. 97, no. 4, p. $290,1964$.

[14] C. Ma and R. A. Eggleton, "Cation exchange capacity of kaolinite," Clays and Clay minerals, vol. 47, no. 2, pp. 174-180, 1999.

[15] J. C. Miranda-Trevino and C. A. Coles, "Kaolinite properties, structure and influence of metal retention on pH," Applied Clay Science, vol. 23, no. 1-4, pp. 133-139, 2003.

[16] O. Ajouyed, C. Hurel, and N. Marmier, "Evaluation of the adsorption of hexavalent chromium on kaolinite and illite," Journal of Environmental Protection, vol. 2, no. 10, p. 1347, 2011.

[17] M. N. Rashed and M. E. Soltan, "Removal of nutrients and heavy metals from urban wastewater using aeration, alum and kaolin ore," in Proceedings of international symposium on environmental pollution control and waste management, 2002, pp. 621-627.

[18] S. M. Awadh and A. A. H. Yousif, "Sorption efficiency of kaolinte in removal Cd from aqueous solutions," Iraqi Journal of Science, vol. 56, no. 2C, pp. 1699-1707, 2015.

[19] S. M. Awadh and H. E. Al-Jubury, "Sorption efficiency of bentonite in removal Cd from aqueous solutions," Iraqi J Sci, vol. 56, no. 2B, pp. 1438-1445, 2015.

[20] S. Veli and B. Alyüz, "Adsorption of copper and zinc from aqueous solutions by using natural clay," Journal of hazardous materials, vol. 149, no. 1, pp. 226-233, 2007.

[21] E. Erdem, N. Karapinar, and R. Donat, "The removal of heavy metal cations by natural zeolites," Journal of Colloid and Interface Science, vol. 280, no. 2, pp. 309-314, 2004.

[22] O. Abollino, M. Aceto, M. Malandrino, C. Sarzanini, and E. Mentasti, "Adsorption of heavy metals on Na-montmorillonite. Effect of pH and organic substances," Water Research, vol. 37, no. 7, pp. 16191627, 2003.

[23] S. Sen Gupta and K. G. Bhattacharyya, "Treatment of water contaminated with Pb (II) and Cd (II) by adsorption on kaolinite, montmorillonite and their acid-activated forms," 2009.

[24] A. P. Ferris and W. B. Jepson, "The exchange capacities of kaolinite and the preparation of homoionic clays," Journal of Colloid and Interface Science, vol. 51, no. 2, pp. 245-259, 1975. 
[25] R. S. Juang, F. C. Wu, and R. L. Tseng, "The Ability of Activated Clay for the Adsorption of Dyes from Aqueous Solutions," Environmental Technology, vol. 18, no. 5, pp. 525-531, 1997.

[26] R. N. Yong, Mohamed, A. M. O. and Warkentin, B.P., Principles of contaminant transport in soils. Elsevier Science Publishers, 1992. 